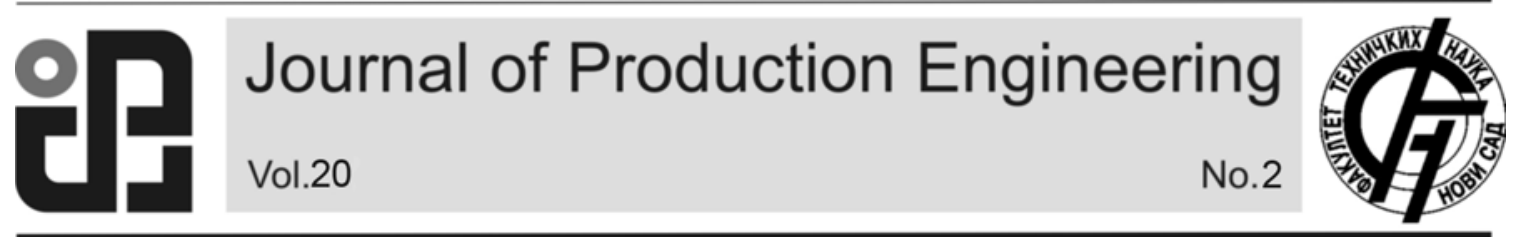

JPE (2017) Vol.20 (2)

Ikubanni, P.P., Komolafe, C.A., Agboola, O.O., Osueke, C.O.

Original Scientific Paper

\title{
MORINGA SEED DEHULLING MACHINE: A NEW CONCEPTUAL DESIGN
}

Received: 10 October 2017 / Accepted: 28 November 2017

Abstract: This work aimed at designing and fabricating a Moringa seed dehulling machine using another design concept. The dehulling mechanisms includes a dehulling shaft that accommodates the dehulling drum of diameter $100 \mathrm{~mm}$ and thickness $2.5 \mathrm{~mm}$ and spikes $40 \mathrm{~mm}$ long. The dehulling machine for Moringa seed processing is powered by an electric motor, pulleys, belts, shafts and bearings. The chaffs leave the machine through a slot created in the dehulling chamber while the seed fall through a screen under the action of gravity to a tray placed under the dehulling chamber. The overall efficiency of this machine on dry basis was $65.9 \%$ and on wet basis was $52.5 \%$.

Key words: dehulling efficiency, dehulling mechanism, moringa dehuller, moringa seed

Mašina za ljuštenje Moringa semena: Novi idejni projekat. Ovaj rad je imao za cilj dizajniranje i izmišljanje mašine za dehuliranje semena Moringa koristeći drugi koncept dizajna. Mehanizmi za ljuštenje obuhvataju oslobađajuću osovinu koja se uklapa u bubanj sa prečnikom od $100 \mathrm{~mm}$ i debljinom od 2,5mm i šiljciama dužine 40 mm. Mašinu za ljuštenje za preradu semena Moringa pokreće električni motor, kutije, kaiševi, osovine i ležajevi. Pleva odlazi iz mašine kroz prorez koji je stvoren u komori za ljuštenje, dok seme pada kroz sito pod dejstvom gravitacije do ležišta postavljenog ispod komore za ljuštenje. Ukupna efikasnost ove mašine na suvoj osnovi iznosila je 65,9\%, a na vlažnoj osnovi bila je 52,5\%.

Ključne reči: efikasnost ljuštenja, mehanizam ljuštenja, moringa ljuštač, moringa seme

\section{INTRODUCTION}

Moringa oleifera, a tree found mainly in the tropic regions, commonly referred to as horseradish or drumstick in English and "ewe ile" in Yoruba. It is the most widely cultivated species of the genus Moringa and has been used by indigenous cultures worldwide for over 4,000 years for various purposes which includes eating, medicinal etc [1] [2]. Moringa is a nutrient-dense plant, rich in calcium, iron, vitamins, and essential amino acids that are found in other complete proteins such as quinoa and meat. Moringa oleifera has many health benefits such as improving energy, lower blood pressure level, lower blood sugar level, improved hair and skin, to name a few [1]. Moringa leaves are believed and reported to prevent over 300 diseases such as diabetes, hypotension, tumour etc., and are used all the time in traditional healing. Moringa, which is the only genus in the family Moringaceae, is an exceptionally nutritious vegetable tree with a variety of potential uses. Every part of Moringa oleifera such as the seed, root and stem are useful. For instance, Moringa oleifera seeds contain flocculants which have tendency to improve water quality. It contains antimicrobial substance and edible oils. The seeds are used to remove lead, iron and cadmium ions from contaminated water [3] [4] [5] [6]. Arthritis, rheumatism, sexually transmitted diseases, hypertension and so on; can be treated using the seed and its oil [7]. The tree itself is rather slender, with drooping branches that grow to approximately 10 metres in height [8]. Moringa is grown in the tropical regions in which Nigeria is part of them. It grows to a height of 5-12 metres with an open umbrella shaped crown, straight trunk and corky, whitish bark, the tree produces a tuberous tap root. The foliage (depending on climate) has leaflets 1 to $2 \mathrm{~cm}$ in diameter; the flowers are white or cream coloured. The fruits (pods) are initially light green, slim and tender, eventually becoming dark green, firm and up to $120 \mathrm{~cm}$ long, depending on the variety. Fully mature, dried seeds are round or triangular, the kernel being surrounded by a lightly wooded shell with three papery wings [9]. The leaves and seeds of Moringa oleifera are good source of protein, vitamins $\mathrm{A}, \mathrm{B}, \mathrm{C}$ and minerals such as calcium and iron [10]. The root, stem and bark can be used to make medicines, perfumes natural pesticides, fertilizers, cleaning agents etc. The oil extracted from the seed can be used for cosmetics, cooking, soap making and the quality of the oil extracted is as good as that of olive oil. Moringa oleifera, kernels also contains a significant amount of oil which is commonly known as Ben oil or Behen oil due to the high concentration of behenic acid contained in the oil. This was erroneously reported to be resistant to rancidity [11]. Moringa seeds are made up of $40 \%$ oil by weight. The cake gotten after the oil has been extracted from the seed can be used as conditioner for the soil or fed to cows to improve their milk production [12].

A lot has been done on the removal of shell for different useful crops such as rubber seed [13], breadfruit seed [14] [15], fluted pumpkin seed [16], melon [17] and so on. However, little design concept has been done on Moringa oleifera seed dehulling as showcased by [2]. Many more design concepts are ongoing for high performance of the Moringa oleifera processing machines so as to enhance the industrial revolution of Moringa oleifera seeds.

In order to extract oil from the seed by an oil extractor, partial dehulling of the shell is important and must be 
done so as to obtain better and higher quality products. When shells are not removed, there is rapid wear and tear on the oil extractor thus its removal reduces damages to oil extractor presses [2].

Therefore, this work is poised to introduce a new concept in the design and fabrication of Moringa oleifera seed dehuller. This machine will save time and energy. It is designed to be operated by any user.

\section{MATERIALS AND METHODS}

\subsection{Machine Conception}

The machine is designed to remove the shell of the Moringa seed. The machine components and system mechanism consist of the following:

1. Hopper: This is the entering point for the seed. It accommodates the seed before moving to the dehulling chamber. The volume of the hopper determines the volume of feed, it can accommodate at once. The hopper is in the shape of frustum of a pyramid.

2. Shaft: This is one of the main components of the machine and is acted upon by weights of material being processed, pulley, impeller blades and the nuts. In operation, the shaft transmits the power being generated by the electric motor through the transmission belt to the dehulling drum which turns the spikes.

3. Main Frame: This is the main body of the machine on which the other members are mounted.

4. Pulley and Transmission Belt: The pulley and belt are transmission system. The belt connects two pulleys. It connects the diving pulley (Electric motor's pulley) to the driven pulley (Shaft's pulley).

5. Dehulling Chamber: This is the place where the dehulling operation occurs. It contains cylindrical drum with spikes attached to it and below it is a screen that lets the seed out.

6. Tray: This is directly below the dehulling chamber and receives the seed after it has been dehulled. The tray is inclined so that the seed roll down under the action of gravity.

\subsection{Operation Mode of the Machine}

The dehulling cylinder with the attached spikes is rotated by the motion provided by the electric motor. The Moringa seeds are introduced through the hopper. The hopper is pyramidal in shape and it is connected to the dehulling chamber of the seed into the rotating dehulling drum. The dehulling chamber is the unit where the pod of the seed is being removed. It consists of a rotating drum with finger-like spikes, the seeds are dehulled using impact force. Inside the dehulling, there is a screen which allows the seed to go through and prevents the pods from passing through. The pods come out through an outlet created in the dehulling chamber while the seeds leave the screen and land on the tray and roll under the action of gravity. The performance of the machine is dependent on the physical properties of the Moringa seed such as the shape, size, moisture content, speed of the machine, effectiveness of the dehulling surface in the dehulling chamber.

\subsection{Material Selection}

Locally available materials were used for the construction of the machine while the strength and quality were not compromised. Mild carbon steel plate and angle bar were used for the construction of the machine. The machine was constructed in such a way that it can be easily assembled and disassembled hence making its maintenance easy. A type A, V-belt was selected due to having long and free life; and used in the transmission of power and torque from its prime mover. The belt is connected to the prime mover which drives the shelling drum with spike shaft.

\subsection{Design Analysis of the Machine Components}

The major design analysis was done on the hopper, shaft, belt drive and power required. The design of the parts of the machine was based on the mechanical and physical properties of the pod.

\subsubsection{Hopper Design}

It is assumed that the hopper is in the shape of frustum of a pyramid and the formula is given as follows:

$$
V=\left(\frac{h}{3}\right)\left(A_{1}+A_{2}+\sqrt{\left(A_{1}+A_{2}\right)}\right)
$$

Where $V$ is the volume of frustum $\left(\mathrm{V}_{\text {frustum }),} h\right.$ is the height of frustum, $A_{1}$ is the area of upper base and $A_{2}$ is the area of lower base

Trapezium formula was used to find the areas since both the upper and lower base are trapeziums.

$$
A=\frac{(a+b) \times h}{2}
$$

Recall:

Volume of the hopper $=$ Mass of feed that the hopper can accommodate

Mass of feed $=$ Density $x$ Volume of the hopper

$$
M=\rho \times V
$$

\subsubsection{Belt Drive Calculations}

Belts are major type of flexible power transmission equipment. It requires relatively close spacing and precise centre distance. It transmits power from motor to shaft, (and the centre distance between motor and shaft is adjustable).

According to Gupta (2006)

$$
\frac{N_{1}}{N_{2}}=\frac{D_{1}}{D_{2}}
$$

Where $N_{l}$ is speed in revolution per minute of motor, $N_{2}$ is speed of the shaft in revolution per minute, $D_{1}$ is diameter of the motor pulley and $D_{2}$ is diameter of the shaft pulley.

Various types of belts exist, however; type A V-belt was chosen.

Therefore, the speed of the driven pulley is calculated using the parameters given in the Table 1 . 


\begin{tabular}{lll}
\hline S/N & Parameters & Value \\
\hline 1 & Electric motor speed & $1400 \mathrm{rpm}$ \\
2 & Center to center distance & $64 \mathrm{~cm}$ \\
3 & Coefficient of friction & 0.11 \\
4 & Angle of Groove & $45^{0}$ \\
5 & Diameter of driver pulley & $70 \mathrm{~mm}$ \\
6 & Diameter of driven pulley & $205 \mathrm{~mm}$ \\
\hline
\end{tabular}

Table 1. Parameters needed to calculate speed of the driven pulley

According to [18], the following models were used Velocity of belt

$$
V_{b}=\frac{\pi N_{1} D_{1}}{60}=\frac{\pi N_{2} D_{2}}{60}
$$

\subsubsection{Belt Length}

The length of the belt will be determined using the equation below:

$L=2 C+\frac{\pi}{2}\left(D_{1}+D_{2}\right)-\frac{\left(D_{2}-D_{1}\right)^{2}}{4 C}$

Where $L$ is total length of the belt (mm), $D_{1}$ and $D_{2}$ are the diameters of the driven and driving pulleys $(\mathrm{mm})$ and $\mathrm{C}$ is the distance between the centres of the two pulleys (mm).

\subsubsection{Angle of Wrap}

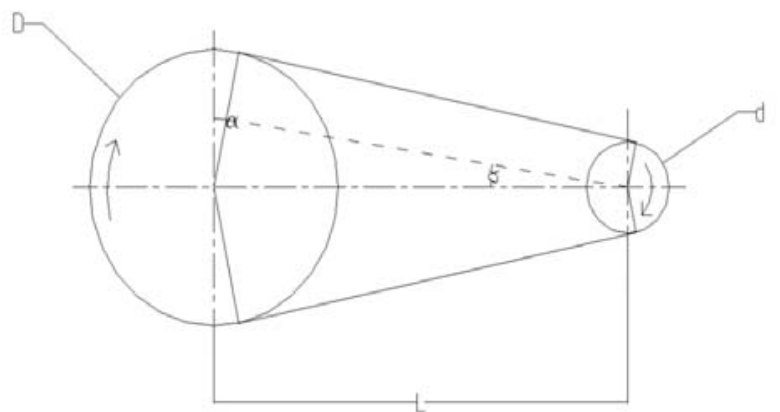

Fig. 1. Open belt drive

A standard belt A type single grooving is selected, whereas the motor can be adjusted horizontally on it supporting slot in other to tension the belt.

For the open belt

$$
\begin{aligned}
& \sin \infty=\frac{D+d}{2 x} \\
& \text { Where } \theta=\left(180^{\circ}-2 \infty\right) \frac{\pi}{180} \mathrm{rad}
\end{aligned}
$$

Where $\theta=$ angle of wrap of an open belt, $\infty=$ angle contanct, $\mu=$ coefficient of friction, $T_{1}=$ Tension in the tight side of the belt, $\mathrm{T}_{2}=$ Tension in the slack side of the belt, $\mathrm{P}=$ Power, and $\mathrm{v}=$ velocity

$$
P=\left(T_{1}-T_{2}\right) v
$$

Tension ratio for an open belt:

$$
2.3 \log \frac{T_{1}}{T_{2}}=\mu \theta
$$

Where, $\mu=$ coefficient of friction between belt and pulley. Coefficient of friction for mild steel pulley and rubber belt, $\mu=0.30$ [18].

\subsubsection{Shaft Design}

The shaft is one of the main components of the machine and is acted upon by weights of material being processed, pulley, impeller blades and the nuts. A mild steel rod of diameter $30 \mathrm{~mm}$ and length $450 \mathrm{~mm}$ was used for the shaft.

The weight of shaft will have effect on the critical speed of the critical shaft.

Critical Speed of Shaft $\left(\omega_{s}\right)=\sqrt{\frac{48 E I}{M L^{2}}}$

Where $\mathrm{E}$ is Modulus of elasticity of steel, I is Moment of initial ( $\left.\frac{\pi d^{4}}{64}\right)$ and $\mathrm{L}$ is the Shaft length.

Calculating the overall critical speed

From Dunkley's formula [19]

$$
\frac{1}{\omega^{2}}=\frac{1}{\omega_{1}^{2}}+\frac{1}{\omega_{2}^{2}}
$$

\subsubsection{Power Requirement}

Power requirement for dehulling drum shaft can be calculated thus;

$\mathrm{P}=$ Torque $\times$ Angular velocity

Torque $=$ Total weight $\times$ radius

\subsubsection{Test Procedure}

The samples of the Moringa seed pods were collected from the University farm. The samples were divided into two. One part was sun dried for about seven days so as to reduce the moisture content of the pods (dry basis) while the other part was not sun dried but stored in polythene bags to maintain their moisture content before the dehulling process (wet basis). Five runs of experiment was carried out on both the dry basis and wet basis. The Moringa pods were fed into the hopper on a continuous approach because the hopper cannot hold all the required quantity for the period of time of the experiment.

\section{RESULTS}

The machine has been designed and the materials for its production have also been stated. The engineering drawings required for the production of the machine has been made available based on the design values obtained. The expected machine operation principle has been highlighted. The efficiency of the machine after the fabrication was determined using the moisture content of the Moringa pods.

Testing the hypothesis that the dehulling efficiency for Moringa seeds with high moisture content reduces the efficiency of the machine and with the lower the moisture content in the pod, the higher the dehulling 
efficiency i.e. increase in moisture content will reduce dehulling efficiency while reduced moisture content will increase dehulling efficiency. This was confirmed as shown in Tables 2 and 3 in which the higher the moisture content in the Moringa pods, the lower the efficiency of the machine and the lower the moisture content in the Moringa pods, the higher the efficiency of the machine.

Thus, dehulling efficiency could be said to be inversely proportional to the moisture content inside the Moringa

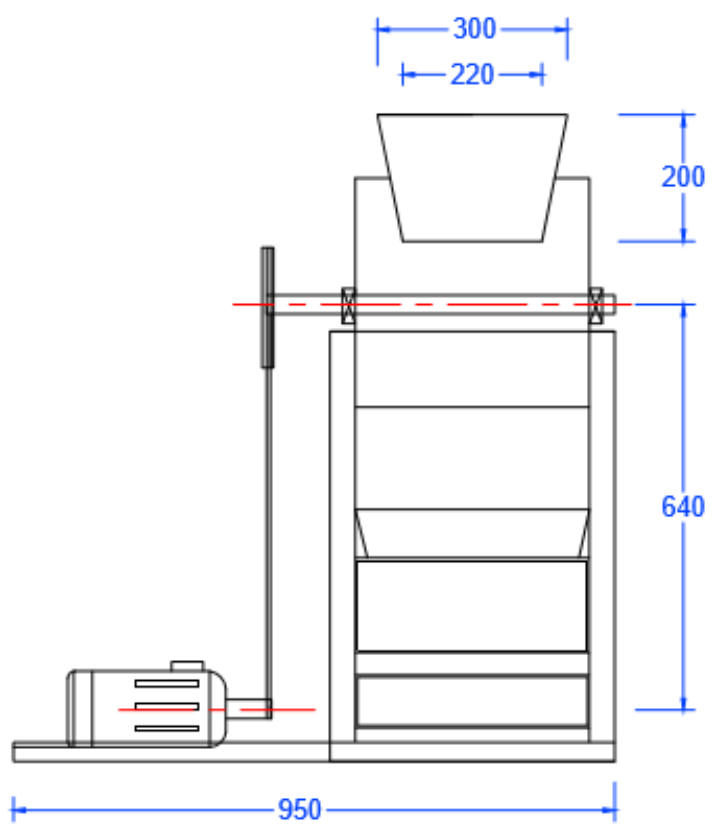

Front view

Fig. 2. Orthographic drawing showing the front and end views of the machine

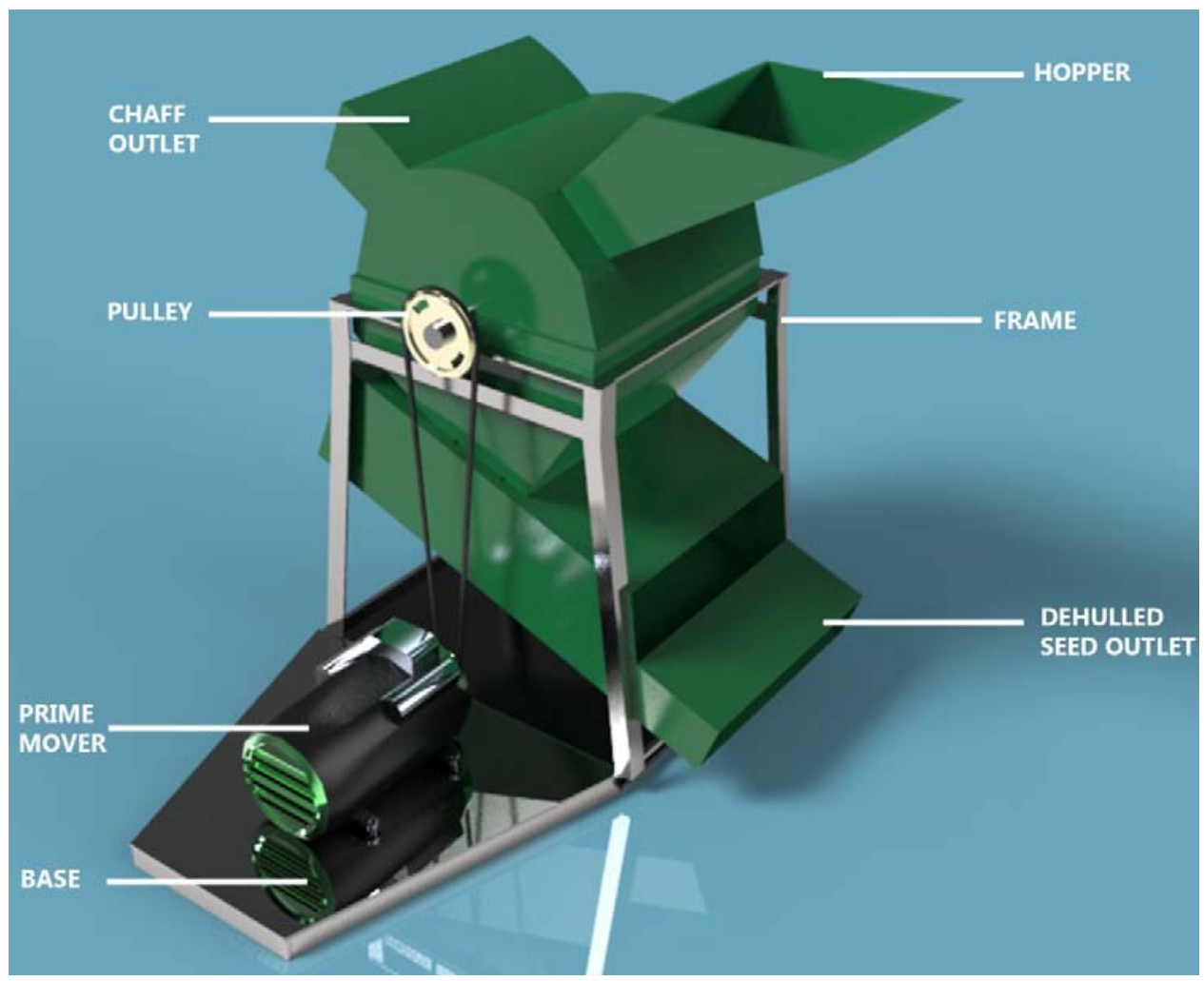

Fig. 3. Isometric drawing of the machine 
Adopting [20] equation for efficiency, the dehulling efficiency for the Moringa dehulling machine was derived using equation (16).

$$
\text { Dehulling Ef ficiency }=\frac{\text { mass of dehulled seeds }}{\text { mass of pods befor dehulling }} \times 100 \%
$$

To calculate loss, equation (17) was used.

Loss $(\mathrm{kg})=$ Mass of whole pod - [Mass dehulled + Mass of chaff]

\section{DISCUSSION}

The preliminary testing of the designed and fabricated machine are as shown in Tables 2 and 3 . From Table 2, the total mass of the pod used for the experiment was $12.3 \mathrm{~kg}$ and the total mass of the dehulled seed was $8.1 \mathrm{~kg}$. Using equation 16 , the average efficiency of the machine was derived to be $65.9 \%$ which gave the same value as finding the average value of the efficiency of each run of the performance evaluation.

From Table 3, the total mass of the pod used for the experiment was $12 \mathrm{~kg}$ and the total mass of the dehulled seed was $6.3 \mathrm{~kg}$. Using equation 16 , the average efficiency of the machine was derived to be $52.5 \%$ which gave the same value as close as finding the average value of the efficiency of each run of the performance evaluation, which was $52.78 \%$.

The moisture content effect on the dehulling efficiency of the machine was determined. Based on the efficiency calculated, the maximum value of the efficiency at between 9 and $11 \%$ moisture content was $65.9 \%$ while the minimum value at between 12 and 15 $\%$ moisture content is $52.78 \%$. The moisture content effect trend on the dehulling efficiency was not determined as performed by [17] and [2]. However, the efficiency of the machine for both the dry and wet are reasonably high. This may be due to the nature of the shell which is soft when moist and brittle when dry [2].

\begin{tabular}{cccccc}
\hline Test & $\begin{array}{c}\text { Mass of whole pod } \\
(\mathbf{k g})\end{array}$ & $\begin{array}{c}\text { Mass of dehulled seed } \\
(\mathbf{k g})\end{array}$ & $\begin{array}{c}\text { Mass of chaff } \\
(\mathbf{k g})\end{array}$ & $\begin{array}{c}\text { loss } \\
\mathbf{( k g})\end{array}$ & $\begin{array}{c}\text { \% } \\
\text { efficiency }\end{array}$ \\
\hline 1 & 2.5 & 1.2 & 1.1 & 0.2 & 48 \\
2 & 2.4 & 1.3 & 0.6 & 0.5 & 54.2 \\
3 & 2.1 & 1.2 & 0.8 & 0.1 & 57.1 \\
4 & 2.3 & 1.3 & 0.5 & 0.5 & 56.5 \\
5 & 2.7 & 1.3 & 0.6 & 0.8 & 48.1 \\
\hline Total & 12 & 6.3 & 3.6 & 2.1 & 263.9 \\
\hline Average & & & & & $\mathbf{5 2 . 7 8}$ \\
\hline
\end{tabular}

Table 2: Performance evaluation of the machine based on dry basis ( $\%$ moisture content between $9 \%$ and $11 \%$ )

\begin{tabular}{cccccc}
\hline Test & $\begin{array}{c}\text { Mass of whole pod } \\
(\mathbf{k g})\end{array}$ & $\begin{array}{c}\text { Mass of dehulled seed } \\
\mathbf{( k g})\end{array}$ & $\begin{array}{c}\text { Mass of chaff } \\
\mathbf{( k g )}\end{array}$ & $\begin{array}{c}\text { loss } \\
(\mathbf{k g})\end{array}$ & $\begin{array}{c}\text { \% } \\
\text { efficiency }\end{array}$ \\
\hline 1 & 2.5 & 1.5 & 0.1 & 0.9 & 60 \\
2 & 2.5 & 1.6 & 0.5 & 0.4 & 64 \\
3 & 2.2 & 1.6 & 0.28 & 0.32 & 72.7 \\
4 & 2.4 & 1.5 & 0.2 & 0.7 & 62.5 \\
5 & 2.7 & 1.9 & 0.4 & 0.4 & 70.4 \\
\hline Total & 12.3 & 8.1 & 1.48 & 2.72 & 329.6 \\
\hline Average & & & & & $\mathbf{6 5 . 9 2}$
\end{tabular}

Table 3. Performance evaluation of the machine based on wet basis ( $\%$ moisture content between $12 \%$ and $15 \%$ )

\section{CONCLUSION}

Based on the design outcome, the Moringa seed dehuller can be used to remove seeds from the Moringa pods and as well separates chaffs/pods from the seeds. In order to maintain simplicity of operation and easy fabrication, the machine is so designed. Due to the simplicity of the machine, it can be conveniently used by Moringa farmers to enable quick and adequate processing of Moringa oleifera seeds. Prior, the Moringa seeds are removed manually which is a serious and laborious task however, by the introduction of this dehulling machine, time energy and cost of production will be saved. Moreover, the components used are strong; the materials are readily available and well selected. The overall efficiency of this machine on dry basis was $65.9 \%$ and on wet basis was $52.5 \%$. The machine can be improved upon so as to aid its efficiency. Also the usage of Moringa pods with lower moisture contents will also improve the efficiency of the machine.

\section{REFERENCE}

[1] Kessler, M.: The Health Benefits of Moringa Seeds. $\quad$ www.doctorshealthpress.com/generalhealth-articles/moringa-seeds-benefits/2016 retrieved February 15, 2017. 
[2] Fadele, O.K., Aremu, A.K.. Design, Construction and Performance Evaluation of Moringa Oleifera Seed Shelling Machine. Engineering in Agriculture, Environment and Food (In press), pp. 1-7, 2016.

[3] Folkard, G., Sutherland, J., Shaw, R.: Moringa oleifera. Water and Environment Health at London and Lough Borough, pp. 109-112, 2004.

[4] Rashid, U., Anwar, F., Ashraf, M., Saleem, M., Yusup, S.: Application of Response Surface Methodology for Optimizing Trans-esterification of Oil: Biodiesel Production. Energy Conversion Management, Vol. 52, pp. 3034-3042, 2011.

[5] Gupta, R.K., Arora, G., Sharma, R.: Aerodynamic properties of Sunflower seed (Helianthus annuus L.), Journal of Food Engineering. Vol. 79, pp.899904, 2007.

[6] Tende, J.A., Ezekiel, I., Dikko, A.A.U, Goji, A.D.T.: Effect of ethanolic leaves extract of Moringa oleifera on Blood Glucose Level of Streptozocin-induced Diabetics and Normoglycemic wistar rats. Br. J. Pharmacol. Toxicol., Vol. 2(1), pp. 1-4, 2011.

[7] Eilert, U., Wolters, B., Nahrstedt, A.: The Antibiotic Principle of Seeds of Moringa oleifera and Moringa stenopetala tala., J. Med. Plants. Vol. 42, pp. 55-61, 1981.

[8] Leone, A., Spada, A., Battezzati, A., Schiraldi, A., Aristil, J., Bertoli, S.: Moringa oleifera Seeds and Oil: Characteristics and Uses for Human Health, Int. J. of Mol. Sci., Vol. 17(12), pp. 1-14, 2016.

[9] Orhevba, B.A., Sunmonu, M.O., Iwunze, H.I.: Extraction and Characterization of Moringa oleifera Seed Oil, Research and Review J. of Food and Diary Technology, Vol. 1, pp. 22-27, 2013.

[10] Dahot, M.U.: Vitamins Contents of Flowers and Seeds of Moringa oleifera, Biochemistry, pp. 2122-2124, 1988.

[11] Nolabigengeser, A., Narasaih, K.S.: Use of Moringa Seeds as Primary Coagulant in Waste Water Treatment, Environmental Technology, Vol. 19, pp. 789-800, 1998.

[12] Irénée, M. B.: Production and Processing of Moringa, Published by "The Technical Centre for Agricultural and Rural Cooperation and Engineers without Borders", 2016.

[13] Fagbemi, E., Ayeke, P., Chimekwene, P., Akpaka,
P., Omonigho, B.: Design of Dehulling Machine and Rubber Seed Processing, American Journal of Science and Technology, Vol. 1(4), pp. 206-212, 2014.

[14] Anosike, N., Brown, E., Maduka, C.: Performance evaluation of a prototyped breadfruit seed dehulling machine, Machines, Vol. 4(11), pp. 1-6, 2016.

[15] Omobuwajo, T.O., Ikegwuoha, H.C., Koya, O.A., Ige, M.T.: Design, Construction and Testing of a Dehuller for African Breadfruit (Treculia Africana) Seeds, Journal of Food Engineering, Vol. 42, pp. 173-176, 1999.

[16] Odewole, M.M., Adesoye, O.A., Oyeniyi, S.K., Isiaka, A.O.: Development and Performance Evaluation of Fluted Seed Dehulling Machines, Arid Zone Journal of engineering, Technology and Environment, Vol. 11, pp. 120-130, 2015.

[17] Shittu, S.K., Ndrika, V.I.O.: Development and Performance Test of a Melon (Egusi) Seed Shelling Machine, Agric. Eng. Int. CIGR J., Vol. 14(1), pp. 157-164, 2012.

[18] Khurmi, R.S., Gupta, J.K.: A Textbook of Machine Design, Eurasia Publishing House Ltd., 7361, Ram Napar, New Delhi, 2006.

[19] Shigley, J.E., Mitchell L.O.: Mechanical Engineering Design (Ed.). McGraw-Hill Book Company, Tokyo, 1983.

[20] Gbabo A., Liberty, J.T., Fadele, O.S.: Design, Construction and Assessment of African Locust Bean (Parkia biglobosa) Dehuller and Separator, International Journal of Engineering and Innovative Technology, Vol. 3(5), pp. 438-444, 2013.

Authors: Engr. Ikubanni Peter Pelumi, Engr. Komolafe Clement Adekunle, Engr. Agboola Olayinka Oluwole, Professor Osueke Christian O. Landmark University, College of Science and Engineering, Department of Mechanical Engineering, Omu-Aran, Nigeria.

E-mail: ikubanni.peter@lmu.edu.ng komolafe.adekunle@lmu.edu.ng agboola.olayinka@lmu.edu.ng osueke.christian@1mu.edu.ng 